\title{
THE FEDERAL URBAN RENEWAL PROGRAM: A TEN-YEAR CRITIQUE
}

\author{
RICHARD H. LEACH*
}

Urban renewal as a federal program began only in 1919 and has been emphasized only since I954. It is important to keep these dates in mind when beginning an appraisal of the program. All new governmental processes require time for public support to be built up and public understanding gained, as well as for problems of operation to be worked out. Perhaps it is too soon to judge urban renewal. It should also be remembered that both the Congresses which have provided for federal assistance in urban redevelopment and the state legislatures which have passed acts enabling local agencies to launch urban renewal projects are, if not actually dominated by rural constituencies, bound by the rural traditions and orientation of American political life. Because urban renewal is new and because it demands for the first time concentrated attention on urban areas, it has been subjected to repeated attack. Every extension has been resisted; and there is still a hearty opposition to the whole idea. Under these conditions, an objective appraisal is seldom encountered.

Granted all this, it seems very possible that history may in the end demonstrate that the Housing Act of $1949{ }^{1}$ which launched urban renewal on its way, is the most significant piece of legislation placed on the federal statute books since World War II. Not only was federal involvement authorized in an activity which "touches practically every phase of the Nation's economy,"2 and thus of its very life, but, what is more, the federal government was enlisted for the duration in the battle for "the elimination of substandard and other inadequate housing through the clearance of slums and blighted areas, and the realization as soon as feasible of the goal of a decent home and a suitable living environment for every American family. ...."3 Perhaps no one foresaw in 1949 that the battle would be such a long one, for, despite the federal government's participation for ten years in the fight against it, the cancer of urban blight has spread since 1949. The life of urban America is still far from being saved. A recent analysis in Boston, for example, concluded that while

- A.B. 1944, Colorado College; A.M. 1949, Ph.D. 1951, Princeton University. Associaze Professor, Department of Political Science, Duke University. Author, [with Alpheus T. Mason] IN Quest oz FreEdom: American Polttical Thought and Practice (1959); [with Redding S. Sugg, Jr.] The Administration of Interstate Compacts (1959); [with Robert H. Connery] The Federal Government and Metropolitan Areas (1960), which devotes considerable attention to housing and urban rencwal. Contributor to periodicals of articles chiefly in the field of American national and state gavernment.

${ }^{1} 63$ Stat. 414, 42 U.S.C. 51450 (1958).

- Growing Problem of Federal Housing Aid, 38 Conc. Dic. 67 (1959). This entire issue is devoted to the growing problem of housing and urban renewal. For an excellent survey of the over-all problem, sce Sogg \& Wertheimer, Urban Renewal: Problens of Eliminating and Preventing Urban Deterioratios, 72 HARv. L. REv. 502 (1959). For a case study of the operation of the program in New York City, see Hershman et al., The How and Why of Tille $I$, I4 THE Record OF THE N.Y.C.B.A. 506 (1959).

- Declaration of Policy, Housing Act of 1949, 63 Stat. 413,42 U.S.C. 5 I44I (I958). 
"Boston's urban renewal program has made discernible progress . . . the rate of renewal activity still is being outstripped by the rate of decay .... [B] etween $195^{\circ}$ and 1960 , it is estimated that ...22,000 more dwellings have fallen into the sub-standard category. This is nearly three times the amount of poor housing eliminated in the last ten years." 4 . What is true in Boston is true in virtually every urban area in the United States. What seemed to be merely a skirmish against slums has turned out to be a war for urban survival. Although the federal government is not fighting the war alone-the states, local governments, and private developers are all allied with her in the struggle-the federal government has come to bear an increasing responsibility for the successful outcome of the battle. In part, this is true because the costs of urban renewal are so great and the federal monopoly of the tax base so tight that effective action by the other governmental members of the team is made very difficult. In part, it is because postwar federal programs in urban areas-public housing, mortgage insurance, highway and airport construction, defense contracts and installations, for example-are creating unprecedented new problems for cities, for the solution of which the federal government cannot avoid assuming responsibility. And, in part, it is simply because two-thirds or more of the people of America live in the battle areas. What affects two-thirds of the nation's population obviously is of intimate importance to the national government.

For all these reasons, there can be no retreat for the federal government from its urban renewal objective. Although President Eisenhower has slowed the fighting down in pursuance of his dual concern for a balanced budget and for what he calls "the traditional framework of our Federal system," even he has declared that "urban redevelopment [is] essential to the future vitality of our cities." And housing legislation continues to be regarded as a major agenda item by both political parties in each session of Congress. Both the Executive and Legislative Branches of the Government recognize the critical nature of the battle and have pledged themselves to eventual victory.

It is important, then, to look back over ten years of urban renewal operations and to judge their effectiveness, for, to employ the military analogy once more, the weapons at hand must be suitable for the battle objectives to be gained, or victory may be impossible from the outset.

As already noted, the statutory authorization for urban renewal is to be found chiefly in Title 1 of the Housing Act of 1949 , as amended." It is important to note that the very title of the Act implics an emphasis on housing rather than on urban renewal. Indeed, the broader subject has been treated all along as merely an aspect of the narrower one. When Congress decided to act in 1949, it saw slum clearance as an adjunct of the housing program, and that relationship has been maintained to

- Boston Municipal Research Blerau, Charting the future of Uriax Renewal iv (1959).

- Budget Message, 1960, in The Bidxet of the United States Guirersmext for the Fiscal Yeak Expisc Juxe 30, 1961, at M40 (1960). See also 1e6 Cosr. Rer. 591 (1960).

- 68 Stat. 622, 42 U.S.C. 51450 (1958). 
the present day. In fact, however, urban renewal and redevelopment is the major task to be accomplished; improved housing is but one aspect of the broader program. Urban renewal means nothing less than full community development, the creation, as Adlai Stevenson put it recently, of "the preconditions of a good urban life that could become a new model for an urbanizing world." Unfortunately, but understandably in the context of pressure politics, Congress seems to see the matter the other way around, so that the focus of its attention-and of appropriations as wellhas been on housing. The pressure for homes right after the war was easy to appreciate. No cause perhaps had more ardent or more politically powerful advocates. The need to save urban centers from progressive blight and eventual strangulation, on the other hand, was complex and hard to grasp; and it lacked persuasive political force. Thus, the resulting emphasis in legislation on the former and not the latter was a natural product of the situation. Not that improved housing was not then and is not still important. There was indeed a mounting housing crisis after World War II, and Congress properly acted to meet it. The difficulty is that in its concern to meet one need, it failed to understand that it was neglecting a greater one. To this day, urban redevelopment has not been brought to the center of the stage where it. belongs; and it suffers from the minor role it has been assigned.

One result of regarding urban renewal as an aspect of the housing program has. been its emphasis on residential building and improvement. Yet residential areasobviously cannot be divorced from the commercial and industrial areas where the people shop and work. The federal program should be amended so as to demonstrate an understanding of this basic fact and to provide for the renewal of nonresidential areas. Seen properly, urban renewal involves the whole life of the urban dweller; seen as a satellite of the housing program, it involves only a part of his life.

The federal urban renewal program suffers, too, from the piecemeal way the housing program has been developed. Different aspects of the program have been handled at different times by different committees in Congress in response to different kinds of pressures. Over the years since 1949, stature has been piled on statute, amendment on amendment, until considerable expertise is needed to comprehend the program. Over forty changes in the law were made by the Housing Act of 1959 alone. 8 The very complexity of the legislation handicaps its effective application. As the mayor of Philadelphia recently testified, the law is "so full of "provided thats' and 'notwithstandings' that it is a nightmare to track down just what is. - provided for." Even the compilation of Federal Laws Authorizing Assistance to Urban Renewval, issued by the Housing and Home Finance Agency, is difficult and. confusing reading. To the lay members, at least, of an Urban Redevelopment Commission, to say nothing of to interested and concerned citizens, the whole program

'Stevcnson, National Purpose: Part II, Extend Our Vision . . to All Mankind, Life, May" 30, r96o, pp. 86, 100.

- See Housing and Hone Finasce Acency, Federal Inhis Atzgeorizing Assistance to Ukban Revewal As Amexded October 1, 1959 (1959).

- Hearings Before the Senate Committe on Banking and Currency on the Housing Aet of 1958, 85th Cong., zd Sess. 293 (1959). 
often appears to be lost in a maze of legal phraseology. Certainly one of the reasons the urban renewal program has been slow to catch the public imagination is because, so complicated has it become, it cannot be communicated easily.

Moreover, obscure and complicated legislation aids and abets delay and red tape, and a universal complaint about the urban renewal program since the beginning has been the "detailed and cumbersome ... procedures and requirements" which it involves. ${ }^{10}$ Often five to seven years have been consumed in processing an urban renewal application. Such delays obviously cause the loss of many opportunities to handle particular urban renewal problems effectively.

The administration of the urban renewal program only makes the situation worse. Although the basic administrative unit is the Urban Renewal Administration, URA is only a child of the parent Housing and Home Finance Agency, the title of which again suggests an unfortunate emphasis. As if it does not trust the child, Congress has endowed the Administrator of the Housing and Home Finance Agency, not the Commissioner of the Urban Renewal Administration, with the responsibility for approving the Workable Programs developed by local communities under the terms of the act. Indeed, administration of the program is highly centralized in HHFA. All contacts outside of Washington must be made with regional HHFA offices, which are chronically understaffed. To be sure, HHFA and URA must protect the funds appropriated for urban renewal by determining the legal eligibility and the practical feasibility of project applications, and in doing so a certain amount of central control is demanded. Many observers feel, however, that far too much control is exercised. Thus, the Baltimore Urban Renewal Study Board, reporting to the Mayor of Baltimore in 1956, complained that "many of the delays and problems encountered ... by local government agencies are due to limitations imposed both by law and administrators at the federal level. A comprehensive renewal program .... is being hampered through unnecessary controls."11 And the Baltimore complaint is not an isolated one.

To make matters still worse, not all federal activities affecting urban renewal are subject either to the HHFA or the URA. The Bureau of Public Roads, the Veterans Administration, the Department of Defense, and the Department of Health, Education and Welfare all carry on activities with a direct impact on urban development, and the programs of a number of other federal agencies have a lesser degree of impact on it.

To some extent, these failings are present in all complex governmental activities. Urban renewal is probably no worse off in this regard than many other federal programs. If the fact that the problem is common to all large-scale government operations excuses the urban renewal program to some extent, however, it must be acknowledged that the basic legislation needs to be simplified and clarified, cumbersome procedures need to be abolished, and lines of authority straightened out. In

${ }^{10}$ Staff of Subcomar. on Intergovernmental Relstions, House Comm. on Government Operajons, 85 th Cong., ist Sess., Sisth Anvual. Report 44 (Comm. Print 1957).

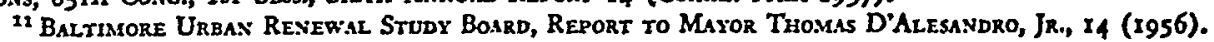


March 1960, Commissioner David M. Walker of the Urban Renewal Administration announced that "Federal regulations guiding the planning and execution of urban renewal projects have been greatly condensed and simplified. . . We now have a single document of clear instructions." "Cities engagcd in Federally-aided urban renewal have long been asking for greater authority and corresponding responsibility," Commissioner Walker went on. The new Urban Renewal Manual, eliminating as it does "many former requirements and greatly simplifying the rest, gives them the freedom and responsibility they want and should have."12 It is, of course, too early to tell if the revised regulations will alleviate the problem and serve to speed up the urban" rencwal process, but at the very least the fact that such a condensation has been made is a giant step in the right direction.

II

The more important faults of the urban renewal program lic in other directions. First and foremost is the fact that urban renewal as a concept has so far been confined to the community, a concept now outdated. Thus, the section of the law requiring a Workable Program specifies that the program shall demonstrate that it deals effectively "with the problem of urban slums and blight within the community" and that it is directed toward "the establishment and preservation of a wellplanned community. ..."13 Loans are authorized to assist local communities to eliminate slums, and the Act specifies that the "governing body of the locality" shall approve the acquisition of real property as the first step in the loan process. ${ }^{14}$ Even the HHFA circular describing the program is entitled "How Localities Can Develop a Workable Program for Urban Renewal."15 Nowhere in the Act is a "community" defined. And although the Administrator is admonished to "encourage the operations of ... public agencies ... on a State, or regional (within a State), or unified metropolitan basis," 16 no specifics are enumerated. As Quintin Johnstone has remarked, "Another point at which the federal urban renewal program is subject to criticism is in its concentration on problems and interests of central cities rather than on [those] of metropolitan areas, of which the central cities are merely a part."12

Section 701 of the Housing Act of 1954 does recognize "planning problems resulting from increasing concentration of population in metropolitan and other urban areas" and authorizes planning assistance grants to statewide, metropolitan and regional planning agencies, which shall be used to plan for "entire urban areas having common or related urban development problems."18 While the assistance thus

19 See U.S. Municipal News, March 20, 1960, p. I.

12 70 Stat. 1103, 42 U.S.C. 5145 (c) (1958). (Emphasis added.)

24 70 Stat. I097, 1099, 42 U.S.C. 1452 (a), (d) (1958). (Emphasis aclded.)

14. Emphasis added.

20 70 Stat. 1103, 12 U.S.C. 51451 (b) (1958).

12 Johnstone, The Federal Urhan Reneural Program, 25 U. Cw. L. Rev. 301, 351 (1958). This article is well worth reading in its entirety.

18 68 Stat. 640, 73 Stat. 678, 40 U.S.C.A. $\$_{461}$ (Supp. 1959). 
authorized has been significant-as of December 31, 1959, ninety-four metropolitan areas, urban regions and special areas had been awarded planning assistance grantsin too many cases official planning agencies operating on the required broader basis are nonexistent. Thus the provision is not as meaningful as it might be. And there is nothing in the law to encourage the establishment of such agencies by the states.

The crux of the matter is that urban renewal cannot properly be considered as affecting only a community, a neighborhood or a locality, in other words, parts of much larger wholes. The effects of slum clearance and urban redevelopmentand of conservation and rehabilitation-reach far beyond the renewal areas themselves and touch the entire urban region of which they are a part. The impact of slums and redeveloped areas on the flight to the suburbs is manifestly a direct one. The economics of the whole urban complex are involved in every renewal project. Highway and street construction, water supply and sewerage, traffic and parking, mass transit, and a host of other activities must all be considered, along with urban renewal, as parts of a single metropolitan picture. Former Housing Administrator Albert M. Cole showed his understanding of the problem in a speech in $1957.0^{18}$

Twenty years ago we thought in terms of individuals.... Then we recognized that this was too limited. ... We began to think in terms of local areas and neighborhoods.... In the Housing Act of 1954 we moved another ... step forward. We dealt with the community as a whole.... But as we top one hill and look ahead, we find an even wider horizon ahead of us-another hill to climb if we are to continue to progress. In these few years I have discovered that even the community is not the final entity that we must consider-that it is part of a growing and expanding urban economy which moves with giant strides not only into the suburbs but into the interurban stretches that no longer define the country and the town. Today it is in these broader terms that we must think and plan-the community as part of the region....

To date, however, the urban renewal legislation has not been altered to bring it into line with such advanced thinking. Just as the 1954 amendments to the original Housing Act raised the sights of the federal government's program from clearing slum pockets to working out an integrated program of community redevelopment, so now the program needs to be amended to permit an all-inclusive approach to the problem of urban decay in metropolitan areas.

There are admittedly legal difficulties barring immediate accomplishment of this objective. The whole metropolitan area problem is made hard to attack by the fact that metropolitan areas, with the exception of the Miami area, have no corporate existence in the United States. Having no legal foundation, they have no over-all governmental organization to which federal grants can be made. If at first glance, however, it appears that this is a problem beyond the reach of the federal government and that under our federal division of powers it belongs to the states, there is, nevertheless, much the federal government could do through its own activities and through its grants-in-aid programs to encourage the creation by the states of larger units of government to fit present and future social and economic realities in metro-

10 Housing \& Home Finance Agency Press Release, June 17, 1957. 
politan areas. The federal government might, for example, require all its grants-inaid programs, housing and urban renewal among them, to be related to comprehensive metropolitan plans rather than, as at present, to comprehensive community plans. It might amend the Workable Program concept so as to include the idea of regional planning. It might require as a condition precedent for federal aid that the local public agency be representative of the entire area rather than of a single city or county. There is something to be said for saving trees; there is much more to be said for saving the forest.

Equally critical to the long-term success of urban renewal is its successful coordination with other urban programs of both the federal and state governments. It has even proved difficult in many cases to coordinate urban renewal and public housing projects in a single city, even though both are activities of the HHFA, for the law permits the public housing and redevelopment programs to be handled by separate local agencies and does nothing to require their coordination. ${ }^{20}$ Moreover, the matter of timing is of crucial importance. Very few cities are able to launch projects under several major programs simultaneously. A city's financial resources are almost always limited, and the amount of state aid available is in most cases not large. Thus many cities may have to forego undertaking an urban renewal project or beginning additional projects in order to take advantage of federal aid in other program areas. This has been particularly evident in connection with the highway program since 1956. The highway program far overshadows the urban renewal program both in the total amount of federal assistance to be offered and in the publicity with which it has been heralded. In the face of such temptation, almost every city faces a very hard problem indeed in achieving a balance in the allocation of its limited resources. "The benefits to be derived from . . . freely-flowing, controlled access expressways might seem so important to a community as to tempt it to concentrate on highways to the exclusion or detriment of ... urban renewal."21 The necessity of making such a choice has become only too common in recent years. "Coordination [would] save public funds and speed both programs." But such coordination has not yet been worked out.

Launched independently as each federal urban program is, there is seldom any effective provision for coordination between them. A common headline across the country in the last few years has been "Delay in Expressway Site Slows Urban - Renewal Plan." In virtually every case, the article following the headline reveals a lack of coordination between the state highway department and the community with a projected redevelopment plan. Mayor Taft of Cincinnati illustrated the problem very well in recent testimony before Congress:

\footnotetext{
${ }^{20}$ See, on this puint, Eduard C. Basifiezd \& Morton Grodzins, Goversient and Housing 69 passim (1958). This book is already a classic in its field.

23 aCTION [AMerican Covicil to Improve Our Neighborkmods, Datton, Ohio], Sumagary of the Midwest Urban Renewal Cinic 21 (1957).

${ }^{2}$ Ihid.
} 
We have a new bridge coming across the Ohio, which is going to be built under the interstate highway program. The approaches on the Ohio side, in the middle of Cincinnati, are 60 acres, and they run through our absolutely worst slums, and they are overlapping our present major redevelopment project which corers 450 acres that include the 60 acres. There the interstate highway and the urban renewal program ... should be operated as a unit in planning and acquiring property."

When land is purchased for highways, whole city lots are acquired, Mayor Taft went on. Frequently, however, a highway uses only a portion of the land acquired, leaving uneven amounts of land on both sides of the highway. "It would make a great deal more sense," the Mayor concluded, "if the urban redevelopment people bought the entire ground and sold back for highway purposes only the right of way.... They would then manage all these little odd pieces that go along the side of the highway...."24 Neither the urban renewal legislation nor the highway legislation makes any provision to accommodate so obviously wise a suggestion.

Nor is any provision made in the highway legislation for the relocation of families which will have to be moved to make way for the urban expressways contemplated by that program. To be sure, aid under section 221 of the Housing Act is available for persons who must be relocated because of highway or expressway construction; but the low maximum amounts per unit allowed by the statute do not attract many builders. As Mayor Richardson Dilworth of Philadelphia has pointed out, if people are not given adequate "help in relocating from the path of highways, this obviously augments the housing problems which the renewal program is trying to solve. . . Renewal activities must be closely related to the programming of highways if we are to avoid, on the one hand, the creation of new blight along new highways, and on the other hand the chewing up of a newly renewed area to make way for a new highway."25 "All of us working in urban renewal ... are missing many a grand chance by not coordinating more closely our freeway and urban renewal plans," concludes a local redevelopment official in Los Angeles. ${ }^{26}$

Similarly, federal activities in the field of recreation, airport construction, water pollution control, civil defense, to name only a few, are all allowed to operate independently and under separate administrative auspices, without a mechanism for coordination. For the most effective operation of each of them, both national and local coordination should be required. One area in particular demands immediate attention. The federal government locates and enlarges its defense and military installations in urban areas virtually oblivious of the impact of such action on the problem of urban redevelopment. Indeed, in the negotiations to obtain a military installation or to enlarge an existing one, it is common for a representative of the chamber of commerce and the congressman from the district concerned to be con-

28 Hearings Before the Senate Committee on Public Works on Federal Aid Highway Act of 1958, 85th Cong., 2d Sess. 613 (1958).

ibid.

${ }^{28}$ Hearings Before the Senate Committee on Banking and Currency on the Housing Act of 1958, 85th Cong, 2d Sess. 293 (1958).

30 Claire, Urban Renewal and Transportation, 13 Traffic Q. 418 (1959). 
sulted; but it is seldom that the city planning director or the head of the local urban redevelopment agency is called in. While this may not be a deliberate oversight on the part of military authorities, since the local people are usually chiefly responsible for determining the composition of the bargaining group, the military authorities have done nothing to facilitate better coordination. In areas where military installations are projected, and metropolitan planning agencies do not exist, the federal government could well take the initiative in bringing together city planners, urban renewal directors, and ather local representatives to consult on appropriate locations. The problem is one of leadership, and it is in the province of Washington to exercise it.

Once again the lack of coordination among federal programs in urban areas is rooted in the fact that metropolitan areas lack any responsible over-all governing body. Thus, urban renewal is parcelled out to the redevelopment agency, expressway construction to the state highway department, airport construction to the airport authority, civil defense to the director of civil defense, and so on. Each moves in the direction that seems best from its limited viewpoint. Perhaps there is no answer, at least no easy answer, to the problem of coordination-and thus to the improvement of this aspect of urban renewal-until some headway is made in attacking the problem of government in metropolitan areas. Here again, however, Washington might lead the way. There are few signs yet that it will do so.

\section{III}

Better coordination of the many government programs having impact on urban areas with urban renewal plans would constitute a major advance. However, the urban renewal program is handicapped in reaching its objectives by more than lack of coordination. To a large degree, the federal government's several housing and mortgage insurance programs work at direct cross-purposes to the urban renewal program. Renewal is largely a matter of the central city. It is chiefly the downtown slum areas which need to be renewed and redeveloped (although slums have popped up already in an alarming number of new suburbs). Slums are primarily multifamily rental residences; and the great need in a redevelopment area is for replacement housing which will accommodate the large number of people being displaced at a rent they can afford, and constructed in a way that will meet their emotional and social needs satisfactorily. The federal mortgage insurance programs, however, operate in almost direct opposition to these requirements. The FHA and GI programs are far more favorable to the construction of single-family homes than to multifamily rental units. FHA regulations do not encourage renovation of old houses in run-down areas. Rather they show decided partiality to the new singlefamily dwelling. And since land for single-family dwellings inside the central city is gererally limited, developers go to the suburbs and erect small houses there. The result of FHA emphasis is that from "every large urban center the suburbs spread 
out and out, without shape or grace or any centered form of civic life. Many are so built that they are the slums of tomorrow."27

Meanwhile, the would-be apartment-house builder is restricted in many ways. To receive federal aid, he must file a cost certificate; if he manages to build below his estimate, he is penalized by having the amount of his mortgage loan reduced proportionately, regardless of the value of the property. Moreover, his profit rate is restricted, his rents are regulated, and he must manage the building over a period of years to get his profit out of the enterprise. All these factors make building needed multifamily rental housing much less attractive to developers than suburban houses and explain, to some extent at least, why so much of the housing built since World War II has been in single-family units.

Nor has the government's public housing program been an adequate substitute. More often than not, the only recourse has been to erect a public housing project in an urban renewal area, but such projects are seldom satisfactory. "These vast, barracks-like superblocks [seem to be] designed not for people who like cities, but for people who have no other choice." ${ }^{28}$ Too many are cut off from city life. They are, to use a term frequently applied to them by their builders, "self-contained." But practice belies the assertion. There is no place in most of them for the development of a community life to replace the very strong sense of community which was characteristic of a great many slum areas. "People get to feel fond of the shabby little drugstore on the corner, or the dusty vacant lot where the kids play stick ball."2t It is hard to feel much warmth toward the sterile structures that have replaced nearly every feature in the neighborhood with which the people were familiar. Not surprisingly, then, in the vicinity of many of the new public housing projects "a host of little enterprises has sprung up ... grocery stores with fruit out front in the strect, discount houses covered with garish signs, pastry shops, delicatessens, a Happy Time Bar and Grill" and a host of other "perversities" to fill the void.30

Moreover, in serving families low on the income scale, public housing has taken an unnecessarily large proportion of broken families, families without a wage-carner, or with family heads chronically unemployed or incapacitated. "As a result, projects have tended to become social and economic ghettos." Moreover, there is "an increasing tendency to locate projects in areas already occupied by nonwhite families, thus decreasing rather than increasing racial democracy." ${ }^{31}$

All these factors lead to the conclusion that public housing projects should give greater consideration to the social needs of the people who are to live therein-both for the sake of their welfare and to assure that the broad objectives of urban renewal

${ }^{27}$ Stevenson, National Purpose: Part II, Extend Our Vision . . to All Mankind, Life, Mag 30, x960, pp. 86, 99.

28 Whyte, Are Cities Un-American?, Fortune, Sept. 1957, p. 123, reprinted in Edrons of FortunE, THe Exploding Metropolis 25 (1958).

${ }^{20}$ See the editorial comment on this point in Saturday Evening Post, Feb. 14, 1959, p. 10.

${ }^{30}$ Whyte, supra note 28 , at 44 .

32 Report of a conference arranged by the Metropolitan Housing and Planning Council of Chicago and ACTION, Feb. 1960, quoted in Sears Urban Renewal Observer, April 1960, p. A. On the latter point, see also Grey, Los Angeles: Urban Prototype, 35 Lawd EcoN. 237-38 (1959). 
will in the end have any meaning. Public housing should be more attractively designed, should look less institutional, less like jails or hospitals-efficient, clean, but a social vacuum. More important they should be designed in recognition of the sociological factors which make for successful community living; they should provide play space for children, meeting places for adults, and recreational facilities for senior citizens, out of which a sense of community can be developed.

Emphasis on public housing for low-income groups has resulted in a failure by the federal government to recognize the nearly as great needs for better housing of the middle-class-income groups in urban centers. Building costs and property values in urban centers have risen faster than the ability of many middle-class-income families to meet them. Yet the public housing limitations on income are too low for them to qualify, even if they wanted that kind of housing. The only answer has been either to desert the central city and join the exodus to the suburbs, or to continue to live in deteriorating houses in deteriorating neighborhoods. As the Senate Subcommittee on Housing reported in April 1960, it is now evident that the housing needs of families of moderate income cannot be met within the foreseeable future "unless new programs for this purpose are fostered by the Federal Government, or by States and local governments, or by all levels of government."32 In recognition of the problem, New York has recently created its own direct loan agency for rental housing to supplement the federal housing program in the middle income areas. Recommending the action, Otto L. Nelson, Jr., chairman of the Governor's Task Force on Middle Income Housing, noted that "a large number of middleincome families have been forced into suburban residences by lack of suitable accommodation at reasonable rents . . . in close-in situations . . . this unbalance has been brought about in part by governmental housing policies not equally beneficial to all housing. The outward trek of the middle-income family has been greatly accelerated by federal home mortgage programs greatly favoring the suburban singlefamily house." ${ }^{\text {"33 }}$ The new state agency in New York is intended to meet the need in that state; there is little doubt that similar action would be beneficial in other states. Once again, leadership from Washington would go far toward providing solutions to the problem.

The problem is not one, however, which can be solved by the Urban Renewal Administration alone. The solution lies deeper than that. It must proceed from a recognition of the fact that urban redevelopment depends on the successful relation - of many different programs one to the others, and that the benefits of action by one agency to assist urban renewal projects may be cancelled by the action of others in building public housing units, encouraging suburban development, building new expressways, or planning a new military installation. To some extent, at least, the more effective coordination of government programs would advance the progress of urban renewal. Yet even this would be to no avail if behind such a move did not

${ }^{32}$ Home Mortgage Credit, Report of Senate Subcommittee on Housing, 106 Cosc. Rec. 7518 (1960).

"ACTION Puts Cost of Total Urban Renewal at $\$ 42$ Billion a Year Over Current Spending, Architectural Forum, May 2960, pp. 5, 67. 
lie an understanding of urban renewal as more than merely removing inadequate housing, but instead as involving every aspect of urban life.

Perhaps the Achilles' heel of urban renewal ${ }^{34}$ will turn out to be the relocation of the residents of areas to be renewed. In New York City alone, as many as 500,000 families-over one fifth of the city's population-will probably be uprooted as urban renewal needs are met in the next fifteen years. Such massive turnover in population has obvious implications for every facet of community life. Some relocation is temporary only. Slums must be torn down before replacement housing can be built. In the meantime, the people who are removed from the site must be housed. More often, relocation is permanent. Although statistics are not easily available, it appears that about a third of the people displaced from renewal areas leave those areas altogether. A movement of that proportion amounts in many cases to mass migration. Unfortunately, however, relocation has too often been treated as a minor problem of secondary importance. It is often handled by a separate agency rather than being coordinated with the urban renewal program. In Boston, in the New York Streets project, the relocation office was established just four weeks prior to the taking of property. "This left too short a period for the staff to become acquainted with the residents and their relocation problems," the Boston Municipal Research Bureau concluded, in a study of the project. ${ }^{35}$ The same kind of thing has happened elsewhere. The federal government could do a great deal toward eliminating the neglect of relocation on the local level if it would spell out in greater detail, and put teeth into, its requirement that a workable program should include a demonstration that families displaced by urban renewal and other governmental activities will be adequately rehoused. Relocation handling should be regularized and not be permitted to rest with the developer, as it does in New York City. Nor should the mere requirement of the statute that displaced people be moved to decent, safe, and sanitary housing be accepted as enough. Too often, relocation results in fact in moving from one substandard housing area to another. The present federal grant of $\$ 200$ to individual family units and $\$ 3000$ to businesses to aid in relocation is not enough in many cases to make a real difference. The whole relocation problem is one which has been neglected and seriously needs attention. Until it and the related problem of providing the type of housing actually needed in renewal areas are solved, the objectives of urban renewal will be frustrated.

\section{IV}

Certainly one of the major problems of the urban renewal program arises out of the fact that while the declared purpose of the program-to provide decent housing and a suitable living environment for all American citizens-is a long-term goal, appropriations have been made on a short-term basis. In the light of the estimates made earlier this year by ACTION that a grand total of $\$ 100$ billion a year should

\footnotetext{
s'The phrase used in a review of J. Anthony Panuch, Rezocation in New Yorx City (1959), in 5 I Planning Bookshelf 3 (1960).

as Boston Municipal Research Buread, Charting the future of Urbas Renewal. 12 (1959).
} 
be spent on urban renewal for the next ten years if the spread of urban blight is to be halted and overcome, ${ }^{36}$ as well as of the survey recently conducted by the American Municipal Association and the United States Conferences of Mayors, which showed an estimated need of a total of $\$ 3,6 \mathrm{r} 7.9$ million in federal grants for urban renewal between now and 1970 , it is obvious that the battle has only been begun. The same figures make it clear that there can be no cut-off date imposed on the program if it is to accomplish its objectives.

Successful planning of so massive a program as urban renewal cannot take place in fits and starts. Officials of local communities believe it is imperative, Senator John Sparkman reported, "that the Federal government be committed to a continuous and adequate urban renewal program to assure the local communities of Federal support as local plans are developed." ${ }^{37}$ Of course, lack of continuity plagues all government programs. One need only cite defense planning to illustrate the point. Continuity of action is a problem across the board in government, and it may well be a problem which defies solution. Even so, a great deal of unnecessary uncertainty and confusion has resulted in the urban renewal program from the two- and three-year authorizations Congress has seen fit to grant. Putting the program on a longer-term basis would remove many of the hardships of planning and would facilitate the operation of the program.

More important, perhaps, is the size of the federal contribution to the program. Federal resources are not without limit, and there is general agreement that both taxes and borrowing are already at uncomfortably high levels. On the other hand, in the latest federal budget, only 0.2 per cent of the proposed expenditures were for urban renewal. President Eisenhower has insisted throughout his administration that the federal portion should not be increased. Indeed, his vetoes of the housing bills have been largely on the grounds of overexpenditure. It is his contention that "nothing is really solved, indeed [that] ruinous tendencies are set in motion, by yielding to the deceptive bait of the "easy' Federal tax dollar." ${ }^{38}$ And the President has a valid point. But it is a truism that the automobile has depopulated the central cities and permitted both industry and upper-income families to migrate to the suburbs, taking with them a large part of the possible tax base. If the cities could develop a practical means of taxing suburban residents and industries who nevertheless receive benefits from their nearness to the central city, reliance on such a tax would no doubt be preferable to federal taxes and federal grants. But no such practical means have been developed. And few states are able to offer much help. The matter boils down very quickly to the fact that, if anything like the proper kind

"ACTION Puts Cost of Total Urban Renewal at $\$ 42$ Billion a Year Over Current Spending, Architectural Forum, May 1960, p. 5.

"Senate Comm. on Banking and Currency, Housing ACt of 1959, SEN. REP. No. 41, 86th Cong., 1st Sess. (1959). See also pro and con discussion, Should Federal Urban Renewal and Public Housing Programs Be Substantially Increased?, 39 Cong. Dic. 76 (1959).

"State of the Union, Address of the President of the United States, ro6 Conc. Rac. 139 (1960). See also H.R. Doc. No. 241, 86th Cong, ad Sess. (1960). 
of action is to be taken, the federal government must support it. It is not a matter of choice; it is a matter of necessity.

The need for continued and increased federal aid becomes even clearer when present commitments are examined. President Eisenhower reported in his Budget Message on January 18 , 1960, that while planning had been initiated on 647 projects in 385 communities, only 26 urban renewal projects had been completed and that only an additional 355 projects for which federal funds had been obligated wcre under way. Sixty-five more projects, the President reported, would be completed by the end of $196 \mathrm{r}$, and 155 additional projects would be gotten under way. ${ }^{39}$ There is thus a considerable gap already between the number of programs planned and those actually under way. And the gap has widened since January I, 1960. On March I, HHFA reported that 115 additional applications for projects had been approved since the last reporting date. Even in New York City, where the need is possibly the greatest, the urban renewal program is essentially only in the planning stage and cannot be expected to move beyond the pilot project stage for several years.

In reality, therefore, urban renewal up to the present has been largely confined to planning. If plans are to move off paper and be converted into concrete, the federal government must honor its commitments. However, it must do more, for projects in many urban areas badly in need of renewal have not yet been planned. Not only is there a backlog of approved plans to be converted into action; there is still a vast reservoir of need to be recognized and reduced to workable programs. The federal government, having launched the program, cannot in justice withdraw until its objectives have been met. Only the federal government has the resources to make fulfillment of those objectives a reality.

\section{$\mathrm{V}$}

Perhaps the most serious weakness of the urban renewal program has been that it was set to work, and has operated since, in a vacuum. From the beginning, it has been marked by a lack of emphasis on research. Very little is known either about the effectiveness of its procedures or about the validity of its goals. In the last ten years, some good private research has been done in the field, and the literature about urban renewal is by now quite respectable.t0 But little attempt has been made to apply what has been discovered to on-going programs. Neither the HHFA nor the URA has a research function. URA does make grants to state and local public agencies for developing, testing, and reporting on improved techniques for preventing slums and eliminating urban blight; and it provides an urban renewal service to assist localities in preparing plans and programs. However, it does not claim to be a research agency itself. The Senate Subcommittee on Housing has recommended

s0 106 CoNG. REc. 59 I (1960).

${ }^{10}$ See appropriate headings in Metropolrtan Cosnivnities: A Bibliograpily (1956); and Metropolttan Comaunities: a Bibliography, Supplenient 1955-57 (1960). 
the establishment of a research program within HHFA, and that recommendation should be acted upon. ${ }^{41}$

Thus, no one is sure what really is the impact of urban renewal projects on the over-all development of the cities in which they are located-to say nothing of the nature of their impact on surrounding metropolitan areas. Despite large federal expenditures over the last ten years and a great deal of organization and activity, no one is sure whether in the long run the result will be good or bad. The millions of dollars being spent for redevelopment are setting the pattern of metropolitan communities for years to come; yet the pattern may turn out to be far from ideal. Conducted, as the urban renewal program is, without necessary correlation with other federal programs in urban areas, it is entirely possible that the end product may be no improvement at all. The tragic thing is that no one seems concerned about finding the answer. The assumption in the program-and the assumption of this author-is that urban renewal is justified and necessary. That assumption should be tested. The present dearth of empirical data and the lack of adequate working concepts must be overcome. This is perhaps the most important step that should be taken.

The difficulty is that that step will probably not be taken, nor will any of the other recommendations made here and elsewhere be put to the test, without effective leadership. There is a pressing need in Washington for real leadership in urban renewal. Congress has provided the tools; the Administration has dragged its feet. President Eisenhower's interest in urban renewal is polite only, and those who have served him in the HHFA and URA have perforce reflected his lack of warmth. Thus, Mayor Leo P. Carlin of Newark, N. J., after meeting for over two hours with HHFA Administrator Norman P. Mason, commented: "We don't feel their hearts and souls are in the [urban renewal] program. We are trying to educate them to go all out. ..."42 Mayor Carlin's feeling has a firm basis in fact. It does not suffice to argue that initiative must be left with localities, that "we must, if we value our historic freedoms, keep within the traditional framework of our Federal system with powers divided between the national and State governments," as President Eisenhower declared in his 1960 State of the Union Address. ${ }^{43}$ The fact is that urban blight is no longer a local problem. Washington has simply failed to wake up to the fact that this is no longer an agricultural country, but one composed chiefly of urban dwellers. The condition of the cities, in which the majority of 'American citizens work, live, and produce the bulk of the nation's economic wealth, is of grave and immediate concern to the federal government. The question of federalism and the distribution of powers between the nation and the states is really beside the point. Indeed, the point is that facts have made the theory irrelevant.

"Home Mortgage Credit, Report of the Senate Subcommittee on Housing, 106 Cong. Rec. 7518-20 (1960). See also S. 3379, A Bill to Establish an Annual or Biannual National Housing Gozl, 86th Cong. 2d Sess. (1959), submitted by Senator John J. Sparkman of Alabama, April 18, 1960 .

${ }^{2}$ Quoted in 106 Cong. Rec. A2720 (1960).

" 206 Cong. Rec. 139 (1960). 
The only issue today is whether the process of decay will be allowed to spread until any action is too late, or whether the federal government will accept its clear responsibility and act to make the objectives of the Housing Act of 1949 a reality. Only a determined leadership, based on an understanding of the real nature of urban renewal and of the defects of the present program, can translate those objectives into fact. 